\title{
A New Occurrence of Protichnites Owen, 1852, in the Late Cambrian Potsdam Sandstone of the St. Lawrence Lowlands
}

\author{
Matthew E. Burton-Kelly ${ }^{* 1}$ and J. Mark Erickson ${ }^{2}$ \\ ${ }^{I}$ Department of Geology and Geological Engineering, University of North Dakota, Grand Forks, North Dakota, 58202, \\ USA; ${ }^{2}$ Department of Geology, St. Lawrence University, Canton, New York, 13617, USA
}

\begin{abstract}
Late Cambrian arthropod trackways from the Potsdam Sandstone have been known since the 1850s. A site in Clinton County, New York, USA, exposes Protichnites in fine-grained, quartz-rich, rippled, micro-laminated Potsdam Sandstone. The study area includes evidence of microbial mat growth on the original surface where the trackways were produced. Ripple marks presumably underlie, and therefore were generated prior to, the microbial mat. Trackway preservation is variable over the outcrop and depositional setting indicates a high intertidal or a low supratidal environment with growth of benthic microbial mats. At least eleven distinguishable trackways of multi-legged, telsonbearing individuals show a range of widths. The trackways consist of repetitive sets of seven pairs of tracks converging in the direction of motion of the organism. A telson impression, either discontinuous or continuous, divides the trackways longitudinally and is nearly centered throughout the lengths of the trackways. The trackways are consistent in number of tracks per series, arrangement, and stride lengths with the ichnospecies holotype from the original description of Protichnites septemnotatus Owen, 1852. Variable preservation probably resulted from varying thickness of the microbial mat and/or varying water depth or wind and wave action in an intertidal pool.
\end{abstract}

\section{INTRODUCTION}

The idea of "explosive" Cambrian diversification [1-3], discoveries of magnificent macro-and microfossil softbodied preservation [4-6], and new attention to preservation in fine-grained intertidal sandstone in the U.S.A., especially of medusae [7, 8] and microbial mat effects [9-12] have caused much interest in the Late Cambrian globally and regionally. Attempts to understand the diversity of Cambrian life on clastic shelves have been made by Drosser and Bottjer [13] from a theoretical perspective. Detailed investigations of trace fossils, such as those by Yochelson and Fedonkin [14] and Drosser et al. [1, 15], have expanded paleontological comprehension of the diversity of life at this critical interval, whereas discoveries of new arthropod types from the Late Cambrian (e.g., [16-18]) have spurred researchers to more closely investigate examples of known trackways and trace fossils from this period.

Through these studies, it has become increasingly apparent that at least some arthropods were making forays into intertidal or perhaps even fully terrestrial areas during the Late Cambrian [7, 19-21]. The earliest terrestrial organisms had free reign over resources that existed out of ecological reach of marine organisms. Determining with precision the age of early amphibious organisms to utilize the intertidal zone as a refuge, a source of nutrients (e.g., microbial mats), or a mating area is important for our understanding of ecological changes in marine and terrestrial settings [22]. This paper continues to examine the clastic marine intertidal setting on Laurentia by illustrating new records of the arthro-

*Address correspondence to this author at the Department of Geology and Geological Engineering, University of North Dakota, 81 Cornell Street Stop 8358, Grand Forks, North Dakota 58202-8358, USA;

E-mail: matthew.burton.kelly@und.edu pod trackway Protichnites Owen, 1852, and by discussing some ecological and behavioral inferences of them.

Specimens of Protichnites ispp. were first observed in the Potsdam Sandstone by Logan [23] in southern Quebec, Canada (Fig. 1). Plaster casts of these traces were shipped from Canada to London, England, where they were formally described by Owen [24, 25] and Logan [26]. Additional casts were sent by Logan to Edward Hitchcock at Amherst College (Massachusetts, U.S.A.) and are now housed at the Pratt Museum [21]. A set of replicas of these casts are in possession of the Geological Survey of Canada [27]. All, presumably, are plastotypes. Other trackway specimens collected by Logan (similar to the type material and the material described here) were examined by the senior author in the collections at the Redpath Museum at McGill University (Montreal, Quebec, Canada). Regretfully, records pertaining to the collection location of these specimens have been lost [27].

Due to near absence of body fossils in the Potsdam Sandstone, the study of these and other sorts of traces, e.g., Climactichnites Logan, 1860, [14, 28] and Diplichnites Dawson, 1873, [29] will have to elucidate the paleoecology of the Cambro-Ordovician beachfront in New York. A rich intertidal/shallow subtidal ichnofauna along with demonstrative tide-generated marine sedimentary facies was described in [30]. The presence of Protichnites in intertidal/low supratidal, and dune sand beds [19] of the Potsdam seems to show some of the first terrestrialization efforts of arthropods [19, 31] in the Late Cambrian. Major re-evaluations of the Proterozoic-Cambrian stratigraphy of the region $[32,33]$ help to place these facies and contained traces into modern, better understood temporal and depositional contexts that will make knowledge of Protichnites valuable more widely around the margin of Laurentia. 


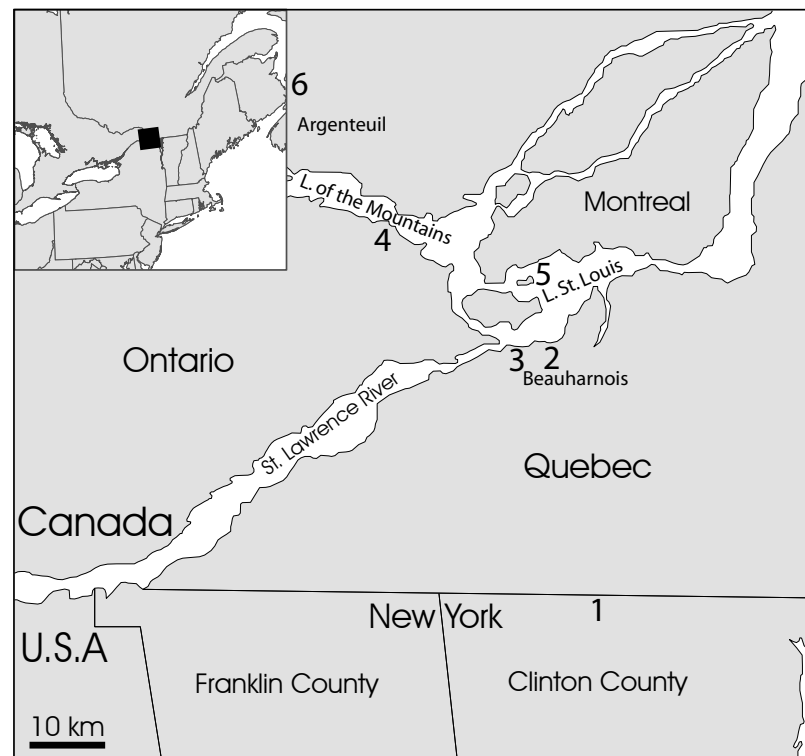

Fig. (1). Location map showing study site in Clinton County, New York, USA. (1) and relationship to localities discovered by Logan [23] and described by Logan [23, 26] and Owen [24, 25] in southwestern Quebec and southeastern Ontario, Canada. Three localities $(2,3)$ were from the area immediate to Beauharnois on the St. Louis River, the others from Point Cavagnol (4) on the south side of the Lake of Two Mountains, one of the islands of St. Généviéve (5) at the south end of the island of Montreal, and the Riviére du Nord (6), in the Seignory of Argenteuil. Locations as mapped by [26]. Present-day accessibility of some sites was discussed by MacNaughton and Hagadorn [27].

The present paper is intended to serve the following purposes: Firstly, to bring attention to an important paleontological site previously undocumented widely in the geologic literature [20,34]; secondly, to describe the multiple trackways present in a modern, quantitative context in order to preserve those data against the eventual loss of the fossils themselves; thirdly, to compare these traces with other examples of Protichnites from the region, which is the type area for this first formally described arthropod ichnotaxon; and lastly, to suggest behavioral and paleoecological interpretations of these early marginal-marine arthropods.

\section{SYSTEMATIC ICHNOLOGY}

\subsection{Ichnogenus Protichnites Owen, 1852}

\subsubsection{Diagnosis}

Trackways of any external width possessing a single medial longitudinal impression (discontinuous or continuous) and a definite (integer) number of tracks per repeating track series sets, paired (i.e., opposing) across the midline.

\subsubsection{Type Ichnospecies}

Protichnites septemnotatus Owen, 1852, by subsequent designation of Häntzschel [35].

\subsection{Nomenclatural Discussion}

Trackways assigned to the ichnogenus Protichnites were first noted in the Potsdam (= Cairnside) Sandstone in the
Montreal Gazette in 1847 [36, 37] and later described by Owen [24, 37] as tracks belonging to, "a species of Terrapene or Emydian Tortoise." The following year, after further study of more specimens [27], he emended his interpretation to describe the producers as arthropods and named the trackways Protichnites [25]. Owen designated six ichnospecies: P. septem-notatus, P. octo-notatus, P. latus, $P$. multinotatus, $P$. lineatus, and $P$. alternans. Hyphens were subsequently dropped as improper per ICZN Article 32.5.2 [38].

Hitchcock [39] worked to standardize Owen's [25] description by listing Protichnites according to the following criteria, possessing: (1) a medial impression, (2) tracksets of five or more, (3) variable track morphologies, (4) variable size, and (5) not limited to any single producer [40]. This designation was little-used to identify trackways, and was effectively nullified when Seilacher [41] suggested that Protichnites be applied to all track-ways with a medial impression and Diplichnites to all those without one. Häntzschel $[35,42]$ later designated $P$. septemnotatus the type ichnospecies for the ichnogenus. His illustrations, however, differed from Owen's [25] written description and plates, notably including a specimen [42, Fig. 61, 1b] with two parallel medial impressions [43].

Keighley and Pickerill [40] presented the most recent attempt to tighten the diagnosis of Protichnites, but in doing so followed Seilacher [41]. The diagnosis presented herein is held to more closely represent the importance Owen placed upon the specific number of tracks per set and to make the identification of Protichnites specimens easier once a complete re-evaluation of the ichnogenus is completed. This is in progress but lies beyond the scope of the present paper.

\subsection{Ichnospecies Protichnites septemnotatus Owen, 1852} (Fig. 2)

\subsubsection{Diagnosis}

Protichnites trackways possessing seven pairs of tracks per series set and either continuous or discontinuous single

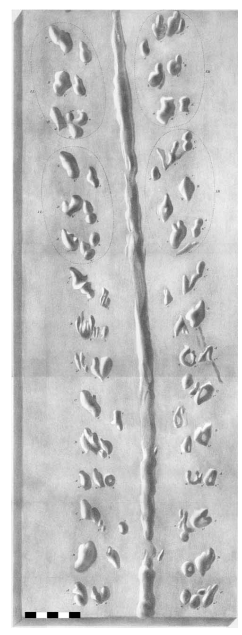

Fig. (2). Plate IX from Owen's [25] original description of Protichnites septemnotatus. Owen's interpretation of track series (circled groups) was different than we present here (Fig. 6). Direction of travel was toward top of figure. Scale bar is $5 \mathrm{~cm}$. 
medial impression, central or marginally placed between opposing track series.

\subsubsection{Remarks}

This diagnosis is less restrictive and more descriptive than it first appears, especially in light of the (now common) trend to not distinguish trackways further than the level of ichnogenus. The trackways described here possess all of the traits in accordance with Owen's description.

\section{OUTCROP AND METHODS}

This study focused on a single bedding-plane exposure [20, 34, 44, Site A] of flat-lying, thinly-bedded, fine-grained Potsdam Sandstone (Fig. 3A) in Clinton County, New York, U.S.A. [32]. This site is part of the Gadway Pine Barrens Reserve of the Adirondack Nature Conservancy and the trackways are protected from removal or damage under this stewardship, which we have honored. The thin bed holding the tracks is exposed in a roadway and it is not well cemented to the bed below (as evidenced by tapping the bed). Casting with latex has been ruled out lest it cause the substrate to peel up when removed. The description provided herein will no doubt be the long-term record of this occurrence. Two additional exposures containing fossil trackways are located nearby on different bedding planes; one three meters to the west and the other $\sim 500 \mathrm{~m}$ to the northeast. Neither has the density, preservation quality or the behavioral information of the site described herein. Additional comments on this area were made by Landing et al. [32].

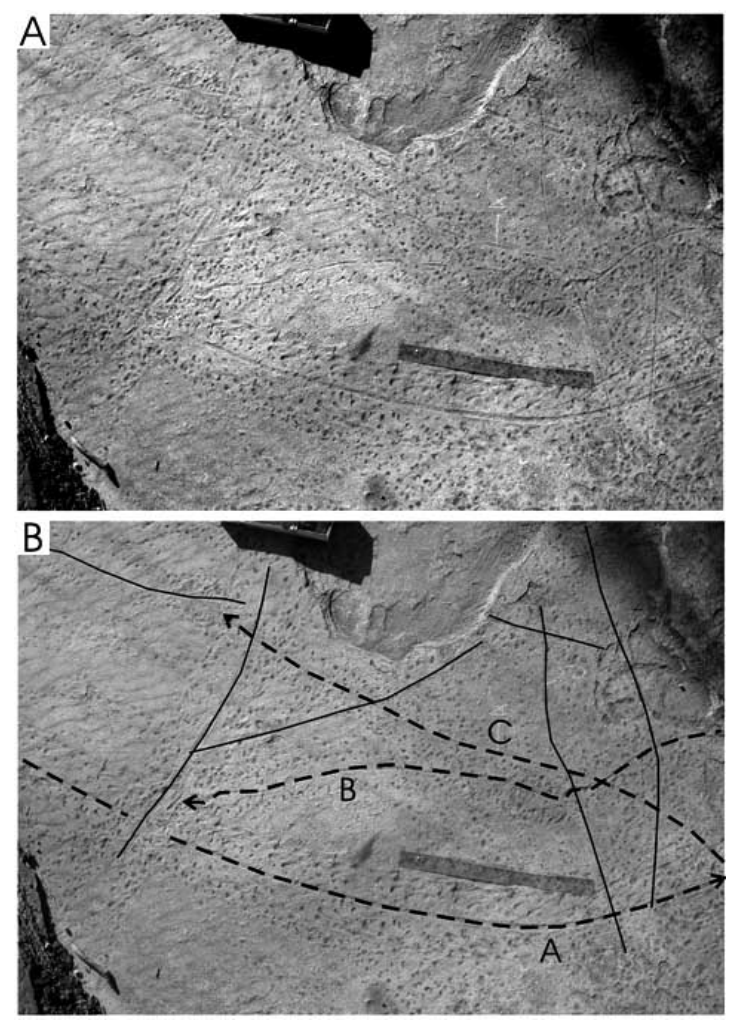

Fig. (3). Aerial view of locality. A) Bedding plane exposure of thinly-bedded or laminated clean siliciclastic Potsdam Sandstone. B) Trackways with direction of travel indicated by arrow. Dashed $\mathrm{A}, \mathrm{B}$, and $\mathrm{C}$ are described herein.
Local topographic relief in the Potsdam Sandstone in this area is less than $0.5 \mathrm{~m}$, and usually less than $0.2 \mathrm{~m}$ over a single outcrop. The outcrop exhibits oscillation ripples, microbial mat textures $[12,45,46]$, repeated mm-scale laminations and mudcracks indicative of shallow water and changing water levels with repetition (tidal cyclicity?) to the deposystem. Oscillation ripples are sinuous with crest-tocrest distance of 20-30 mm (mean $23 \mathrm{~mm}, \mathrm{n}=12$ ) and ripple crests trend approximately northeast/southwest. At least 11 trackways are visible, three of which (trackways A, B, and C) are described in detail here (Fig. 3B). They do not seem to have a preferred orientation. Most of the trackways are too poorly preserved to distinguish series order; taphonomic grade of each trackway was not noted but preservation of trackway A is better than that of B, which is better than that of C. Many scattered impressions are present that cannot be resolved into organized trackways, however all stride lengths and relative track positions are very consistent along the length of each trackway we describe. Trackways A and B intersect each other; trackway $\mathrm{C}$ does not. All tracks are inphase across the medial line. Trackways were photographed and rubbings were made of the trackways in situ but casts have not been made for reasons noted above.

\subsection{Methods of Track Identification}

Table 1 defines terminology used. Terminology used herein follows Minter et al. [47] in most cases, the exception being the difference between 'tracks' and 'imprints.' The terminology in Minter et al. [47] assumes that a distinction between 'tracks' (discrete marks produced by walking limbs) and 'imprints' (discrete marks produced by other anatomical structures) can be made, where previous terminologies [48] have included 'tracks' as a subset of 'imprints' (defined therein as any discrete mark produced by an organism). This latter definition of 'imprints' is preferred because it allows reference to 'discrete marks produced by an organism which may or may not be tracks,' something that is often the case. To be precise, one would always use 'tracks' when referring to marks interpreted as having been produced by a walking limb, 'non-track imprints' when referring to marks that are not being interpreted as tracks (but are being interpreted as being produced by a living organism), and 'imprints' when referring to marks that are interpreted as being produced by a living organism but are unable to be connected to a particular aspect of the anatomy of the producer.

The outcrop was visited first in April 2002 and revisited in September and October 2004 to make direct measurements. Because snowfall and trackway access were early problems, the majority of data collection and interpretation relied on digital photographs (greater than 3.0 megapixels) taken perpendicular to the bedding plane in low-angle light, which proved to be very satisfactory when printed on a large format plotter. Two photographs were printed at near life size $(92.9 \%$ and $87.2 \%)$; measurements made from these photographs were scaled accordingly. Individual imprints and medial impressions were traced onto clear acetate from whence a series of tracings and photocopies was made. Imprints with discernable edges were marked without regard for depth of the imprint.

Track series were designated by locating repetitions of the same tracks at fixed intervals along the length of the 
Table 1. General Notation (Variable Throughout Trackway Literature) Herein Follows [48, 67, 68]. Notation Specific to the Arrangement and Order of Individual Imprints Follows [40]

\begin{tabular}{|c|c|}
\hline Term & Definition \\
\hline Impression & Mark appearing related to the presence of an organism. \\
\hline Track & Imprint repeating itself at regular intervals, typically interpreted to have been produced by a single limb. \\
\hline Trail & Any continuous impression. \\
\hline Midline & Theoretical line parallel to the long axis of the trackway and located halfway between the external margins. \\
\hline Medial & Referring to imprints positioned anywhere between the greatest lateral extent of the trackway. \\
\hline Stride & $\begin{array}{l}\text { Distance between two adjacent tracks on the same side of and measured parallel to the medial line. Note again that } \\
\text { tracks occur at standard intervals. }\end{array}$ \\
\hline Width & Distance between outer edges of tracks measured across the midline. \\
\hline
\end{tabular}

trackway in each case. This was accomplished by overlaying traced groups of imprints on other sections of the trackway to look for repetition of: (1) distance between imprints, (2) distance of each imprint from the mid-line, and (3) shape of imprint. Regular repetition of an imprint in the same position in each set led to its identification as a track produced by the same walking limb. These methods were used until the unassociated imprints were exhausted, or until no spatial relationship could be found between any of the remaining unassociated imprints. Each repeated group of tracks was designated a series. These methods were used to resolve trackways $\mathrm{A}, \mathrm{B}$ and $\mathrm{C}$ and to correlate between the related tracks across different series and across different trackways. Correlated impressions are designated by the same label and color in Fig. (4A-C). Note that there are a variety of ways in which these tracks can be divided into series, but not all of them could have been produced by a living organism $[25,48$, 49]. Several methods of 'idealized' track arrangements were applied here before arriving at the interpretation described.

Method of labeling tracks follows that of Keighley and Pickerill [40], who used R1, R2, R3, etc. and L1, L2, L3, etc. to designate tracks belonging to the same series on right and left sides of the trackway, respectively. Paired tracks nearest the mid-line (i.e., having the smallest distance between internal edges) in all trackways were labeled R0/L0. The impressions second-nearest to the mid-line and closest (along the length of the trackway) to tracks R0/L0 were marked as R1/L1, etc. Order of track numbering does not imply order of track production.

\section{DESCRIPTION OF TRACKWAYS}

\subsection{Trackway A (Fig. 4A; Tables 2, 3)}

Trackway A consists of repeated series of seven oval or longitudinally tapered tracks on each side of a medial impression 1.5 meters in length. Over the course of $0.92 \mathrm{~m}$ there are 152 imprints of which 110 have been identified as tracks (Fig. 4A).

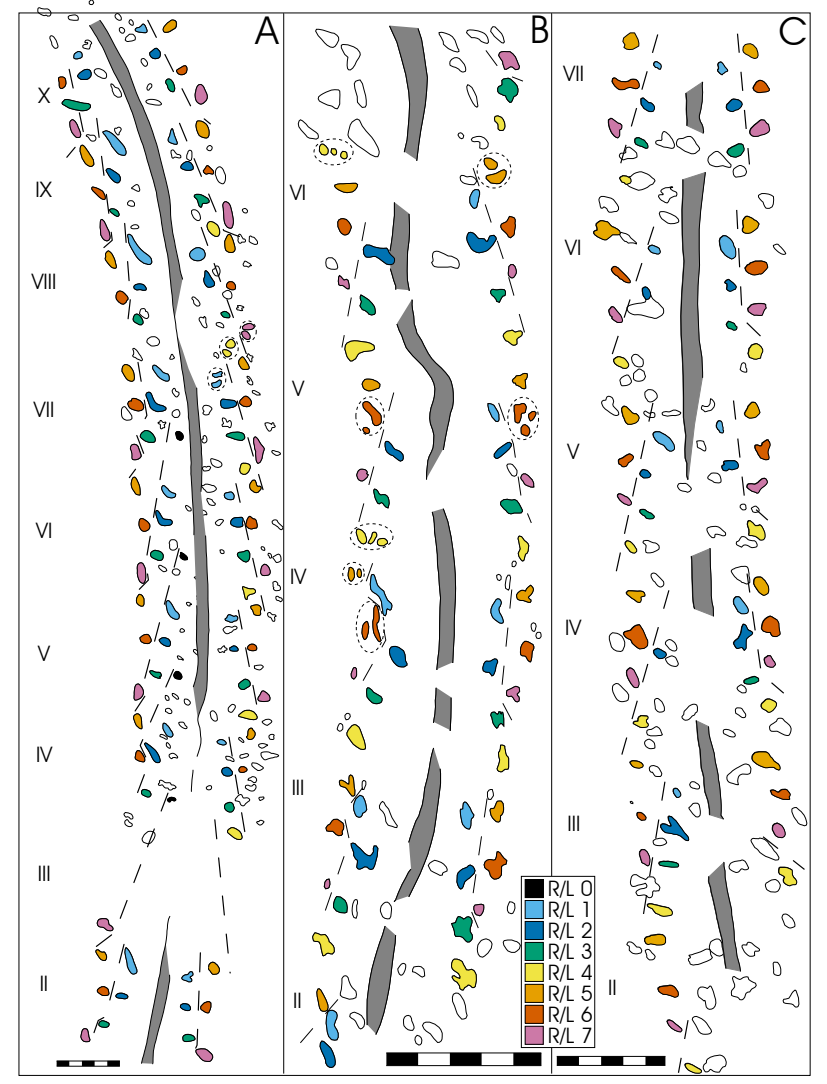

Fig. (4). Schematic diagram of described trackways with correlative coloring of identified tracks. A) Trackway A. B) Trackway B. C) Trackway C. Dashed lines separate neighboring track series, labeled by Roman numerals. Dashed circles indicate possible multipart imprints. Coloring is the same across trackways. Direction of travel was toward top of figure. Trackways are not to same scale; scale bars are $5 \mathrm{~cm}$.

Tracks from 10 series sets are apparent. The medial impression is continuous and remains in the middle of the 
Table 2. Morphometric External Width Data of Trackway A (Format after [65]). (*) Indicates Widths Estimated by Doubling the Distance between the Opposite Track and Axis of the Medial Impression. (-) Indicates a Missing Value

\begin{tabular}{|c|c|c|c|c|c|c|c|c|}
\hline \multirow{2}{*}{ Set } & \multicolumn{8}{|c|}{ Width (mm) } \\
\hline & R0-L0 & R1-L1 & R2-L2 & R3-L3 & R4-L4 & R5-L5 & R6-L6 & R7-L7 \\
\hline I & - & 62 & 65 & 89 & - & - & - & - \\
\hline II & $30 *$ & - & - & - & - & 107 & 98 & 115 \\
\hline III & $48^{*}$ & 56 & 78 & 81 & $100 *$ & - & - & $130^{*}$ \\
\hline IV & $34 *$ & 62 & 68 & 87 & $110^{*}$ & 105 & 97 & - \\
\hline V & $30 *$ & 62 & 75 & 86 & $92 *$ & 107 & 100 & 117 \\
\hline VI & - & 59 & 77 & 90 & $92 *$ & 112 & 101 & 114 \\
\hline VII & - & 63 & 69 & 88 & $82 *$ & 109 & 106 & 115 \\
\hline VIII & - & 58 & 73 & 86 & $88^{*}$ & 110 & 103 & $120^{*}$ \\
\hline IX & - & 67 & 74 & 95 & - & 111 & 105 & 114 \\
\hline $\mathrm{X}$ & - & - & - & - & - & $120 *$ & $106^{*}$ & 120 \\
\hline Mean width (mm) & - & 61.13 & 72.38 & 87.75 & - & 108.71 & 101.43 & 115.83 \\
\hline Standard deviation $(\mathrm{mm})$ & - & 3.40 & 4.60 & 3.99 & - & 2.50 & 3.41 & 2.32 \\
\hline Est. mean width $(\mathrm{mm})$ & 35.30 & 61.13 & 72.38 & 87.75 & 94.00 & 110.13 & 102.00 & 118.13 \\
\hline Est. standard deviation & 8.54 & 3.40 & 4.60 & 3.99 & 10.8995 & 4.61 & 3.55 & 5.38 \\
\hline
\end{tabular}

paired series. Some non-track imprints are located in the medial impression (width 7 to $9 \mathrm{~mm}$ throughout). The average external width of the track farthest from the mid-line (R7/L7) is $116 \mathrm{~mm}(\mathrm{n}=6)$ (Table 2). The average stride on the right side of the trackway (outside of gentle curve) is 103 $\mathrm{mm}(\mathrm{n}=40)($ Table 3). Strides on the left side of the track average $99 \mathrm{~mm}(\mathrm{n}=35)$. Track morphology on the left side of the medial line seems to be significantly different from that on the right, the tracks most proximal to the medial line being longer and more tapered. There is no change in stride length or opposite-track width through the area where this trackway intersects with trackway B. Maximum trackway width is $\sim 119 \%$ of mean stride length. Individual tracks are oval (long axis parallel to trackway axis) or tapered (shallow-and-narrow end pointing in the direction of travel). Some tracks seem bifid or trifid, although these multipleimprint tracks are inconsistent. Tracks L0 and R4 each have no opposite counterpart.

\subsection{Trackway B (Fig. 4B; Tables 4, 5)}

Trackway B (Fig. 3B) consists of a discontinuous medial imp-ression flanked by repeated series sets of seven tracks of varying morphology. The portion that is preserved in enough detail to study contains 112 imprints and 74 identified tracks in a $0.42 \mathrm{~m}$ distance (Fig. 4B). The trackway is oriented at a high angle relative to trackway A where it becomes visible on the outcrop (right of Fig. 3), then abruptly changes direction and continues through a gentle curve.
Tracks representing six series sets are apparent. The medial impression is discontinuous and does not remain on the mid-line throughout. The length of the medial impression, where it is present, ranges from 15 to $50 \mathrm{~mm}$ (mean $42, \mathrm{n}=6$ ) with an intermediary distance ranging from 5 to 35 $\mathrm{mm}$ (mean 21, $\mathrm{n}=6$ ). In one instance (sets IV and V) the medial drag is erratic. The average external width of the trackway at its widest point $(\mathrm{R} 6 / \mathrm{L} 6)$ is $65 \mathrm{~mm}(\mathrm{n}=4)$ (Table 4). Stride lengths on the right side of the trackway average $79 \mathrm{~mm}(\mathrm{n}=24)$ (Table 5). The average stride length on the left side is $76 \mathrm{~mm}(\mathrm{n}=23)$. Maximum trackway width is $\sim 90 \%$ of mean stride length. Most tracks are nearly subcircular or sub-oval with long axes parallel to the mid-line. Track identifications were also assigned to more linear than round imprints in some cases.

\subsection{Trackway C (Fig. 4C; Tables 6, 7)}

Trackway $\mathrm{C}$ exhibits many characteristics similar to trackways A and $\mathrm{B}$. The medial impression is discontinuous and 8 to $11 \mathrm{~mm}$ wide. Medial impression segments are 30 to $55 \mathrm{~mm}$ long (mean 38, $\mathrm{n}=9$ ) with an inter-segment distance of 10 to $40 \mathrm{~mm}$ (mean $28, \mathrm{n}=8$ ). Tracks along $77 \mathrm{~cm}$ of the medial impression are clear enough to be examined, but series sets could only be resolved over $48 \mathrm{~cm}$. This distance includes 127 imprints, 56 of which have been associated with series (Fig. 4C). Tracks are sub-circular or oval with varying angle of long axis to the trackway. The trackway curves slightly to the right (towards top of Fig. 3) viewed in the direction of travel. Maximum trackway width is $\sim 86 \%$ of mean stride length. 


\begin{tabular}{|c|c|c|c|c|c|c|c|c|c|c|c|c|c|c|}
\hline & 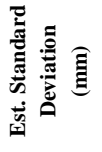 & $\stackrel{\infty}{\stackrel{\infty}{\rightarrow ~}}$ & तె & $\vec{m}$ & $\overline{\widehat{i}}$ & $\stackrel{\vartheta}{\dot{m}}$ & $\stackrel{7}{m}$ & $\stackrel{\infty}{\text { j) }}$ & $\begin{array}{l}\tilde{n} \\
\hat{n}\end{array}$ & $\stackrel{?}{\sim}$ & & & & \\
\hline & 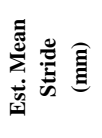 & $\stackrel{\square}{\circ}$ & 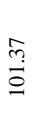 & 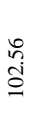 & $\begin{array}{l}\stackrel{+}{+} \\
\stackrel{d}{d}\end{array}$ & $\begin{array}{l}8 \\
\text { d. } \\
\text { I. }\end{array}$ & 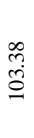 & $\begin{array}{l}\stackrel{n}{a} \\
\infty\end{array}$ & $\begin{array}{l}\stackrel{8}{0} \\
\ddot{\alpha}\end{array}$ & $\begin{array}{l}\text { त्रे } \\
\text { ूू }\end{array}$ & & & & \\
\hline & 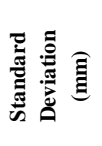 & | & గ్రి & $\begin{array}{l}\mathscr{m} \\
\dot{m}\end{array}$ & $\begin{array}{l} \pm \\
\text { i }\end{array}$ & $\stackrel{\vartheta}{m}$ & $\stackrel{7}{m}$ & $\stackrel{\bar{n}}{n}$ & $\begin{array}{l}\tilde{\infty} \\
\dot{\sim}\end{array}$ & $\stackrel{?}{\sim}$ & & & & \\
\hline & 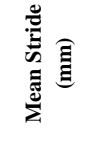 & I & $\begin{array}{l}8 \\
\text { \& } \\
\text { o }\end{array}$ & $\begin{array}{l}\text { ì } \\
\text { d }\end{array}$ & $\begin{array}{l}\stackrel{e}{0} \\
\stackrel{0}{0}\end{array}$ & 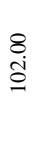 & 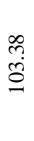 & $\begin{array}{l}\stackrel{n}{\hat{\infty}} \\
\infty \\
\alpha\end{array}$ & $\begin{array}{l}\stackrel{\partial}{\ddot{~}} \\
\ddot{\alpha}\end{array}$ & $\begin{array}{l}\text { त्रे } \\
\text { nू }\end{array}$ & & & & \\
\hline & 5 & 1 & ฉ & 蒿 & 䓂 & $\stackrel{\Omega}{\varrho}$ & $\stackrel{\Xi}{\Xi}$ & $\begin{array}{l}\text { 卷 } \\
\stackrel{0}{\circ}\end{array}$ & $\begin{array}{l}\text { *ै } \\
\stackrel{2}{\circ} \\
2\end{array}$ & \& & $\begin{array}{l}\stackrel{0}{0} \\
\stackrel{\infty}{\circ}\end{array}$ & శึ & $\begin{array}{l}\hat{\sigma} \\
\infty \\
\sigma\end{array}$ & $\underset{\text { in }}{\overrightarrow{0}}$ \\
\hline & $\approx$ & I & 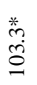 & 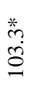 & $\begin{array}{l}\text { m. } \\
\stackrel{\overbrace{}}{\varrho}\end{array}$ & $\stackrel{\infty}{\varrho}$ & ڤ̊ & $\stackrel{\varrho}{\varrho}$ & 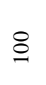 & $\varrho$ & $\begin{array}{l}\stackrel{8}{0} \\
\stackrel{\sigma}{\varrho}\end{array}$ & 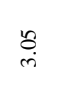 & $\begin{array}{l}\stackrel{n}{c} \\
\text { है }\end{array}$ & $\overrightarrow{\mathrm{i}}$ \\
\hline & صٌ & | & 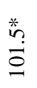 & 蒡 & 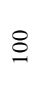 & $\stackrel{\circ}{\circ}$ & $\stackrel{\wp}{\varrho}$ & 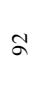 & 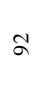 & 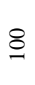 & 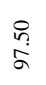 & 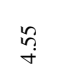 & $\begin{array}{l}\text { in } \\
\infty \\
\infty\end{array}$ & 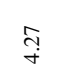 \\
\hline$\widehat{\widehat{\mathrm{g}}}$ & $\dddot{q}$ & I & $\begin{array}{l}\text { in } \\
\text { î. } \\
\text { S. }\end{array}$ & 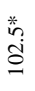 & $\cong$ & 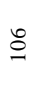 & $\hat{\wp}$ & 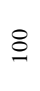 & \& & $\infty$ & $\stackrel{7}{\circ}$ & 古 & $\begin{array}{l}\stackrel{n}{\stackrel{\delta}{\delta}} \\
\stackrel{0}{0}\end{array}$ & $\begin{array}{l}\text { ț } \\
\text { in }\end{array}$ \\
\hline$\stackrel{\Xi}{E}$ & 3 & 1 & $\stackrel{*}{\stackrel{*}{\varrho}}$ & $\stackrel{*}{\circ}$ & $\stackrel{\varrho}{\varrho}$ & 5 & à & $\hat{a}$ & $\bar{\sigma}$ & I & $\begin{array}{l}\stackrel{8}{+} \\
\text { a }\end{array}$ & $\stackrel{\stackrel{J}{+}}{+}$ & $\frac{ \pm}{\infty}$ & $\stackrel{\infty}{\stackrel{m}{m}}$ \\
\hline & $\dddot{2}$ & | & $\frac{*}{n}$ & مُ & 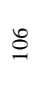 & $\stackrel{ \pm}{\stackrel{0}{0}}$ & $\stackrel{\curvearrowleft}{\varrho}$ & ऽิ & $£$ & $\alpha$ & $\begin{array}{l}\vdots 0 \\
\stackrel{0}{0}\end{array}$ & 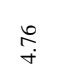 & $\begin{array}{l}\hat{0} \\
\stackrel{0}{0}\end{array}$ & $\underset{+}{\stackrel{\delta}{+}}$ \\
\hline & \pm & I & 1 & 1 & 1 & 1 & I & I & 1 & I & | & I & 1 & 1 \\
\hline & $\underset{\approx}{ \pm}$ & I & 1 & ฮै & $\cong$ & $\stackrel{\varrho}{\varrho}$ & $\hat{\wp}$ & $\stackrel{\varrho}{\varrho}$ & I & I & $\begin{array}{l}\stackrel{8}{0} \\
\stackrel{0}{0}\end{array}$ & $\stackrel{ \pm}{\stackrel{m}{-}}$ & $\begin{array}{l}\stackrel{8}{0} \\
\stackrel{0}{0}\end{array}$ & $\stackrel{ \pm}{m}$ \\
\hline & 3 & 谷 & 关 & $\stackrel{\Xi}{\varrho}$ & $\stackrel{\varrho}{\varrho}$ & 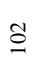 & 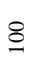 & $\approx$ & $\stackrel{2}{\circ}$ & I & $\begin{array}{l}\text { in } \\
\text { à }\end{array}$ & $\overrightarrow{\mathrm{r}}$ & $\begin{array}{l}3 \\
\stackrel{0}{0}\end{array}$ & $\underset{i}{\stackrel{i}{i}}$ \\
\hline & $\cong$ & 蒿 & 总 & 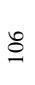 & $\stackrel{\text { a }}{ }$ & $\hat{\varrho}$ & $\stackrel{ \pm}{\Xi}$ & 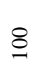 & $\bar{\Xi}$ & I & 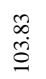 & $\bar{m}$ & 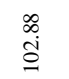 & $\vec{m}$ \\
\hline & $\mathcal{I}$ & 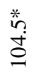 & 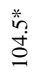 & $\approx$ & $\stackrel{ \pm}{\Xi}$ & aे & 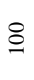 & $\stackrel{\infty}{\circ}$ & $\&$ & I & $\begin{array}{l}\hat{b} \\
\stackrel{+}{\sigma}\end{array}$ & 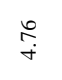 & 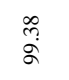 & $\frac{i}{i n}$ \\
\hline & $\approx$ & 苍 & $\stackrel{\text { ̈̈ }}{0}$ & 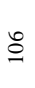 & $\stackrel{\infty}{\varrho}$ & ఏ & 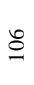 & 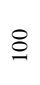 & aे & I & $\stackrel{m}{\varrho}$ & $\stackrel{\infty}{\stackrel{\infty}{\infty}}$ & $\begin{array}{l}\& \\
\ddot{0} \\
\stackrel{0}{0}\end{array}$ & $\stackrel{\text { ते }}{\text { ri }}$ \\
\hline & $\Xi$ & 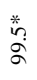 & 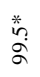 & ฮั & $\bar{\varrho}$ & $\bar{\Xi}$ & $\stackrel{\infty}{\varrho}$ & 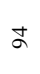 & $\tilde{\infty}$ & I & $\begin{array}{l}8 \\
\infty \\
\infty\end{array}$ & $\vec{\sigma}$ & 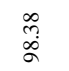 & $\stackrel{n}{r}$ \\
\hline & $\bar{\approx}$ & $\stackrel{*}{\Xi}$ & $\stackrel{*}{\stackrel{*}{\sigma}}$ & 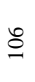 & $\cong$ & $\nsubseteq$ & $\stackrel{\infty}{\varrho}$ & ऽิ & 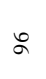 & I & 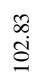 & $\underset{f}{\stackrel{f}{f}}$ & 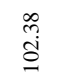 & $\begin{array}{l}\vec{\infty} \\
\stackrel{\sim}{\infty}\end{array}$ \\
\hline & $\stackrel{\rho}{ }$ & I & $\stackrel{n}{\varrho}$ & $\hat{\varrho}$ & $\stackrel{\infty}{\varrho}$ & I & 1 & I & I & 1 & $\begin{array}{l}50 \\
\stackrel{0}{\circ} \\
0\end{array}$ & $\stackrel{n}{n}$ & $\begin{array}{l}\overleftarrow{b} \\
\stackrel{0}{0}\end{array}$ & $\stackrel{n}{n}$ \\
\hline & 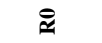 & I & 1 & I & I & I & 1 & 1 & | & I & | & I & 1 & 1 \\
\hline & $\ddot{\mathscr{\nu}}$ & $\Xi$ & $\stackrel{\text { 䳔 }}{ }$ & $\stackrel{\text { 引 }}{\Xi}$ & $l^{3}$ & $\begin{array}{l}5 \\
>\end{array}$ & $\underset{>}{5}$ & $\underset{\mid}{\stackrel{B}{\mid}}$ & 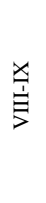 & $\begin{array}{l}\stackrel{x}{x} \\
\ddot{x}\end{array}$ & 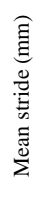 & 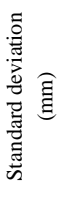 & 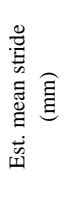 & 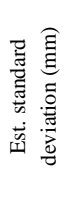 \\
\hline
\end{tabular}


Table 4. Morphometric External width Data of Trackway B (Format after [65]). (*) Indicates Widths Estimated by Doubling the Distance between the Opposite Track and the Medial Impression. (-) Indicates a Missing Value

\begin{tabular}{|c|c|c|c|c|c|c|c|}
\hline \multirow{2}{*}{ Set } & \multicolumn{7}{|c|}{ Width } \\
\hline & R1-L1 & R2-L2 & R3-L3 & R4-L4 & R5-L5 & R6-L6 & R7-L7 \\
\hline I & $34 *$ & $36^{*}$ & - & - & - & - & - \\
\hline II & 45 & 48 & 54 & 64 & $46^{*}$ & - & - \\
\hline III & 50 & 41 & 53 & 62 & 63 & 69 & 60 \\
\hline IV & $44 *$ & 48 & 55 & 64 & 70 & 65 & 64 \\
\hline $\mathrm{V}$ & $54 *$ & 50 & 55 & 67 & 62 & 65 & 67 \\
\hline VI & - & - & $74 *$ & 67 & 64 & 67 & 67 \\
\hline VII & - & - & - & - & - & - & $68^{*}$ \\
\hline Mean width (mm) & 47.50 & 46.75 & 54.25 & 64.80 & 64.75 & 66.50 & 64.50 \\
\hline Standard deviation (mm) & 3.54 & 3.95 & 0.96 & 2.17 & 3.59 & 1.91 & 3.32 \\
\hline Est. mean width $(\mathrm{mm})$ & 45.40 & 44.60 & 58.20 & 64.80 & 61.00 & 66.50 & 65.20 \\
\hline Est. standard deviation (mm) & 7.54 & 5.90 & 8.87 & 2.17 & 8.94 & 1.91 & 3.27 \\
\hline
\end{tabular}

Tracks from seven series are present and have the same arrangement as in trackways $\mathrm{A}$ and $\mathrm{B}$. The external width (R6/L6) of the trackway averages $72 \mathrm{~mm}(\mathrm{n}=5)$ (Table 6). The trackway is straight along section analyzed. Average stride length on the right is $82 \mathrm{~mm}(\mathrm{n}=22)$ and on the left is $84 \mathrm{~mm}(\mathrm{n}=26)$ (Table 7).

\section{DISCUSSION}

\subsection{Preservation}

Portions of the track-bearing surface exhibit textures such as "elephant skin" [45] (Fig. 5A, C) and erosional pockets characteristic of microbial mats $[45,46]$. Ripple marks (Fig. 5B, D) have been cut through by tracks and associated imprints, and apparently underlie (and therefore were generated prior to) the microbial mat surface. Hagadorn and Bottjer [10] previously noted the presence of trace fossils (Diplichnites, Planolites, Taphrhelminthopsis and Paleophycus) made by trace-makers interacting with wrinkled surfaces and have noted the role of these mats in preservation of trackways. The bedding plane on which the trackways are preserved was part of a high-intertidal or lowsupratidal environment, possibly inundated only at springtide-like intervals. High intertidal to supratidal habitats have been postulated for microbial mats in similar settings [45]. Tidal evidence in the Potsdam Sandstone in association with arthropod trackways was first noted by Logan [50], who described repeated sequences of water-ripple marks and windblown sand deposits directly below his trackways. Other examples of wind-deposited sand and microbial binding of sediment (biofilms and stromatolites) can be found in the Nepean Formation in and around Ottawa, Ontario, Canada [51]. Herringbone cross-strata of presumed tidal origin are also a common feature of this portion of the formation though not directly associated with these traces.
The organisms were present and producing trackways at (or very nearly) the same time. Ripple marks were produced by wind over a tidal pool. The track producers were probably partially supported by water, where the body of the organism could have been held afloat above the substrate [52]. The presence of the microbial mat texture suggests that these impressions are not undertracks. Although the mat may have formed and then have been subsequently inundated and buried, the presence and depth of a large number of impressions and the medial impression show that any penecontemporaneous sediment overlying the now-exposed bedding plane would not have been very thick. The size and orientation of ripples preserved under the algal mat seem unlikely to be related to the distances between adjacent sections of the intermittent medial track structure. It is postulated that the intermittency of the medial structure was caused by wind-wave action similar to that which caused the sediment ripples. Eventual covering of the bedding plane may have been accomplished by eolian processes [51]; windoscillated water would be insufficient to cause this preservation [53]. The presence at this site of trackways associated with microbial mats suggests that the preservation potential may have been enhanced by this association, similar to circumstances described by Hagadorn and Seilacher [54]. No evidence of grazing was seen in association with these trackways.

\subsection{Ichnotaxonomy}

The trackways described here are assigned to Protichnites septemnotatus based on their comparison with Owen's [25] original description. They are very similar to the trackways illustrated [25, Plate 9] in number of tracks per series, arrangement, and angle of track series to mid-line (Figs. 2, 6). Opposing tracks in the same series set are inphase, implying that the organism was adapted for swimming rather than terrestrial life [55]. While Owen found it most likely that the animal producing the tracks was 


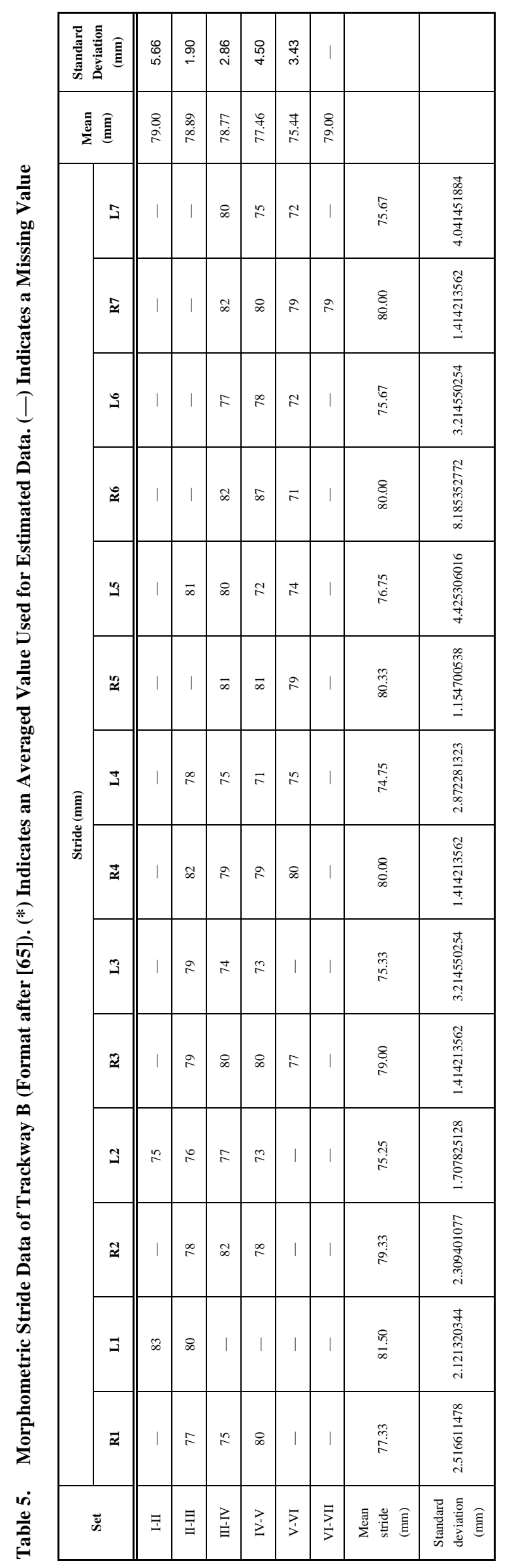

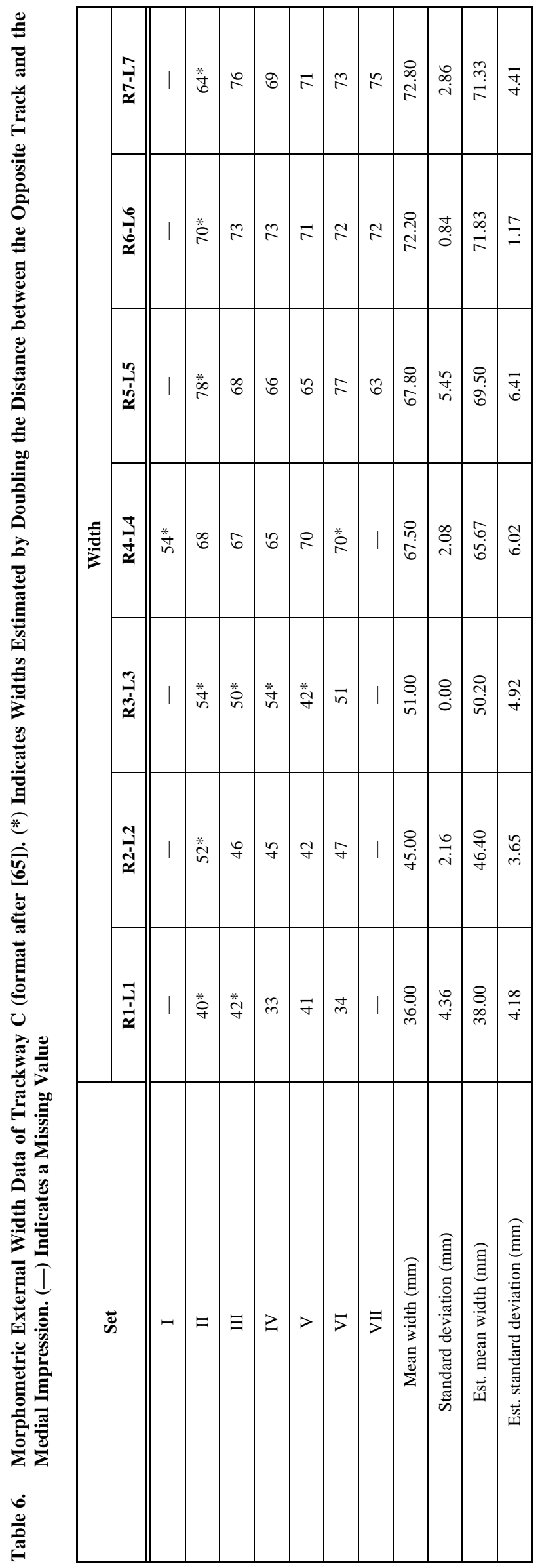


Table 7. Morphometric Stride Data of Trackway C (Format after [65]). (*) Indicates an Averaged Value Used for Estimated Data. (一) Indicates a Missing Value

\begin{tabular}{|c|c|c|c|c|c|c|c|c|c|c|c|c|c|c|c|c|c|c|}
\hline \multirow[b]{2}{*}{ Set } & \multicolumn{18}{|c|}{ Strides } \\
\hline & R1 & L1 & R2 & L2 & R3 & L3 & R4 & L4 & R5 & L5 & R6 & L6 & R7 & L7 & $\begin{array}{l}\text { Mean } \\
(\mathbf{m m})\end{array}$ & $\begin{array}{c}\text { Standard } \\
\text { Deviation } \\
(\mathbf{m m})\end{array}$ & $\begin{array}{c}\text { Est. } \\
\text { Mean } \\
\text { Stride } \\
(\mathbf{m m})\end{array}$ & $\begin{array}{c}\text { Est. } \\
\text { Standard } \\
\text { Deviation } \\
(\mathbf{m m})\end{array}$ \\
\hline I-II & - & - & - & - & - & - & - & 75 & - & - & - & - & - & - & 75.00 & - & 75.00 & - \\
\hline II-III & - & $81.5^{*}$ & - & 82 & - & $59.5^{*}$ & 79 & 86 & - & 81 & - & 81 & - & 80 & 81.50 & 2.43 & 78.75 & 8.04 \\
\hline IV-V & 83 & 88 & 83 & 84 & $82 *$ & $86^{*}$ & 83 & 86 & 80 & 83 & 82 & 83 & 82 & 83 & 83.33 & 2.02 & 83.43 & 2.03 \\
\hline $\mathrm{V}-\mathrm{VI}$ & 83 & 85 & 84 & 88 & 82 & $86^{*}$ & - & 85 & 87 & 87 & 84 & 85 & 82 & 86 & 84.83 & 1.95 & 84.92 & 1.89 \\
\hline VI-VII & - & - & - & - & - & - & - & - & 80 & 88 & 85 & 89 & 83 & 88 & 85.50 & 3.51 & 85.50 & 3.51 \\
\hline $\begin{array}{l}\text { Mean } \\
\text { stride } \\
(\mathrm{mm})\end{array}$ & 83.33 & 86.50 & 82.33 & 84.25 & 82.00 & - & 81.33 & 82.80 & 82.50 & 83.40 & 82.25 & 84.20 & 81.25 & 84.00 & & & & \\
\hline $\begin{array}{l}\text { Est. } \\
\text { mean } \\
\text { stride } \\
(\mathrm{mm})\end{array}$ & 83.33 & 84.00 & 82.33 & 84.25 & 82.00 & 72.75 & 81.33 & 82.80 & 82.50 & 83.40 & 82.25 & 84.20 & 81.25 & 84.00 & & & & \\
\hline $\begin{array}{c}\text { Est. } \\
\text { standard } \\
\text { deviation } \\
(\mathrm{mm})\end{array}$ & 0.58 & 3.14 & 2.08 & 2.63 & 0.00 & 15.30 & 2.08 & 4.66 & 3.32 & 4.16 & 3.10 & 3.03 & 2.22 & 3.08 & & & & \\
\hline
\end{tabular}

hexapodous with bifurcate or trifurcate legs, he did recognize that the association between what he considered trifurcate tracks was not proven and that any animal with any number of legs between six and fourteen could have produced his original Protichnites trackways. Fig. (6) applies labels to Plate 9 of the original description of $P$. septemnotatus to show that the interpreted arrangement of tracks for the trackways described here can also be applied to the type specimen.

Ichnotaxa should be based on morphology, not upon the identity of the interpreted producer. Therefore it should be noted that an organism defined as the producer of these particular trackways has no effect on their designation as $P$. septemnotatus. Keighley and Pickerill [40] summarized very well the criteria upon which a named ichnotaxon must be based. Trewin [48] added that interpreted direction of movement should also be disregarded when defining traces. If direction of movement is an applicable diagnostic tool, new ichnotaxa could be generated from the same trackways simply by interpreting the direction of movement differently, which would be counter to the idea of keeping ichnotaxonomy as unambiguous as possible. Many of the criteria and philosophies behind ichnotaxonomy were standardized by Bertling et al. [56] in hopes of improving communication.

Trackways A, B, and C are made up of series consisting of tracks that are similar in order and relative position. These trackways are therefore assigned to the same ichnospecies and are likely to have been produced by the same kind of organism. Trackways $\mathrm{B}$ and $\mathrm{C}$ were produced under the same environmental conditions (tide-pool wavelets causing discontinuous medial impressions), while trackway A was probably produced under different conditions (calm water allowing a continuous medial impression) and hence at a different time.

\subsection{Probable Tracemakers}

We suggest an invertebrate animal with seven pairs of walking limbs, with the possibility of additional limbs held out of contact with the substrate. The regularity and large number of tracks, in addition to their geologic age, rules out most organisms, leaving arthropods as the most likely producers [57, 58]. Although Walcott [36] attributed Protichnites trackways to species of Dikelocephalus, a trilobite, it seems unlikely that a trilobite of this size would have produced such well-defined trackways with no extraneous impressions (e.g., gill marks) in an intertidal pool. Absence of any trace produced by the genal margins of the cephalon is also reason to exclude Dikelocephalus and most other Cambrian trilobites, and Dikelocephalus did not possess a telson. The absence of trilobite body fossils from the Potsdam Formation in the St. Lawrence Valley is well known. Cruziana, a potential trilobite trace, appears only rarely in the section in the Theresa-equivalent March Formation of Ontario, Canada, well above the Potsdam [30].

MacNaughton et al. [19] and Braddy [31] attributed similar trackways to members of the Euthycarcinoidea, which 
possessed 11 pairs of uniramous pre-abdominal limbs (as reconstructed by Trewin and McNamara [43] and Vaccari et al. [17]) and ranged from the Late Cambrian to Middle Triassic [17]. The euthycarcinoid body plan seems discordant with the trackways presented herein because the limbs of the euthycarcinoids decrease in length both anteriorly and posteriorly from the middle of the preabdomen [17] whereas the limbs in question here appear to have increased in length from anterior to posterior.

Arrangement of the tracks described here is reminiscent of those made by Braddy and Almond's [55] reconstruction of the walking pattern of the eurypterid Onychopterella augusti, but the Eurypterida were limited to 5 pairs of limbs used for locomotion [59]. The Burgess Shale fauna seems to yield no good candidates for producers that would either be able to support themselves out of water, or be large enough to produce these trackways. The trackways described here are consistent with an organism with generally shorter anterior limbs. A number of tracks could be indicative of bifurcate or trifurcate walking limb termination (Fig. 4A, B). While these examples have been marked as such, the only evidence for their association comes from their relative location to tracks one stride away in either direction. Depending on the ability of the producer to manipulate the terminal morphology of specific limbs, any apparent reduction from proven bifid or trifid tracks (c.f. Kouphichnium) may be a result of poor preservation. We are confident that all of the trackways described here were produced by the same type of organism. In determining a producer this is presently unimportant; no known fossil exactly conforms to a morphological descrip-tion able to produce these trackways.

During the Late Cambrian a wide array of arthropod clades were available to supply the track makers including stylonurans, synxiphosurans, phyllocarids [60], aglaspidids [60], trilobitomorphs, euthycarcinoids [17, 60], xiphosurans [18] and possible as yet undiscovered merostomes [61], their morphologic requirement being presence of seven or more ambulatory appendages and a telson. When found at the end of a trackway, the producer will finally be certainly known.

\subsubsection{Functional Morphology of Producers}

Owen [25] reported that in some cases his specimens exhibited intermittent medial impressions. He associated each interval where the central impression was present with a specific trackset, implying that the presence or absence of a tail drag was related to the walking cycle of the animal. Anderson [49] made this association with Petalichnus. Hoxie [21] noted that specimens of Protichnites he examined did not exhibit medial impressions that (when intermittent) crossed or traveled outside of the tracksets, a condition that is matched in the Protichnites trackways described herein and suggests a short telson relative to body length. There exist no known trackways with a continuous impression that crosses one of the paired trackrows. Variation in distance of the medial structure from the mid-line is indicative of a telson of some length rather than a fixed ventral or posterior process. Intermittency of medial impression, when concurrent with a specific phase of the walking cycle would, however, be a strong reflection of production by a ventral process rather than a telson.
The specimens described herein do not exhibit a clear association between medial impression intermittency and tracksets. It is suggested here that the intermittency of the medial impression results from the effect of small windgenerated waves upon the partially buoyant organism in a few centimeters of water. Under such conditions a telson could react independently from the body of the trackway producer, which could accommodate changes in water depth by flexing or repositioning its legs or being large enough so as not to be affected. The telson flexure ability of modern Limulus means that active control of the impressionproducing structure cannot be ruled out, though it is passively dragged up the beach [62]. Medial impression intermittency appears to be randomly distributed along trackways in comparison with preserved ripple marks and is therefore unrelated to either erosion of ripple crests (or nonmarking of ripple troughs) or to variation in preservation over the course of a single trackway.

The presence of a telson raises the question of its intended use-was it a defensive structure, an attack structure, or something else? The interpreted short length relative to the length of the organism seems to rule out the telson's role in aggressive behavior, and as a defensive structure it would face the same morphological deficits. Following a modern analogue of Limulus, the most likely use for the telson by these organisms would have been to right themselves if deposited upside-down on the substrate.

Since the regular swimming motion of modern Limulus is sufficient for movement and reorientation in the water column, this adaptation would not be retained if Limulus did not periodically make forays onto land. Likewise, the producers of these trackways, if possessing (as the evidence seems to show) an active telson, would not have required such an adaptation if they did not pass through the swash zone and shoreface, where wave action or even strong winds may have flipped an organism onto its back. This use of the telson in Limulus to right itself has been verified by Fisher [63] and Penn and Brockmann [62].

\subsubsection{Direction of Travel}

Tracks appearing on the outside of curves in the trackway are typically separated by a greater stride length, showing roughly the ability of the producer to turn and (potentially) the 'sag' of the legs, i.e., the comparison of the horizontal distance between the joint of the leg with the body during 'normal' locomotion and the track produced by that leg with the most extreme possible extension. The disparity between the two sides is most visible in tracks R1 and R2 in trackway A (Fig. 4A). The deepest part of these tracks is to the rear (bottom of figure), tapering and shallowing to the front. This was most likely caused by a limb dragging through the sediment at the beginning of another step (c.f. [64, Fig. 6]. This evidence supports a converging-forward series direction of travel as suggested by the "tear-shaped morphology" [55] of eurypterid tracks pointing in the direction of travel. The notation used to label the tracks as discussed in this paper is in no direct way related to the stepping pattern utilized by the organism which produced each of the trackways. Different stepping patterns utilized may have varied along the length of a trackway and between different trackways. 


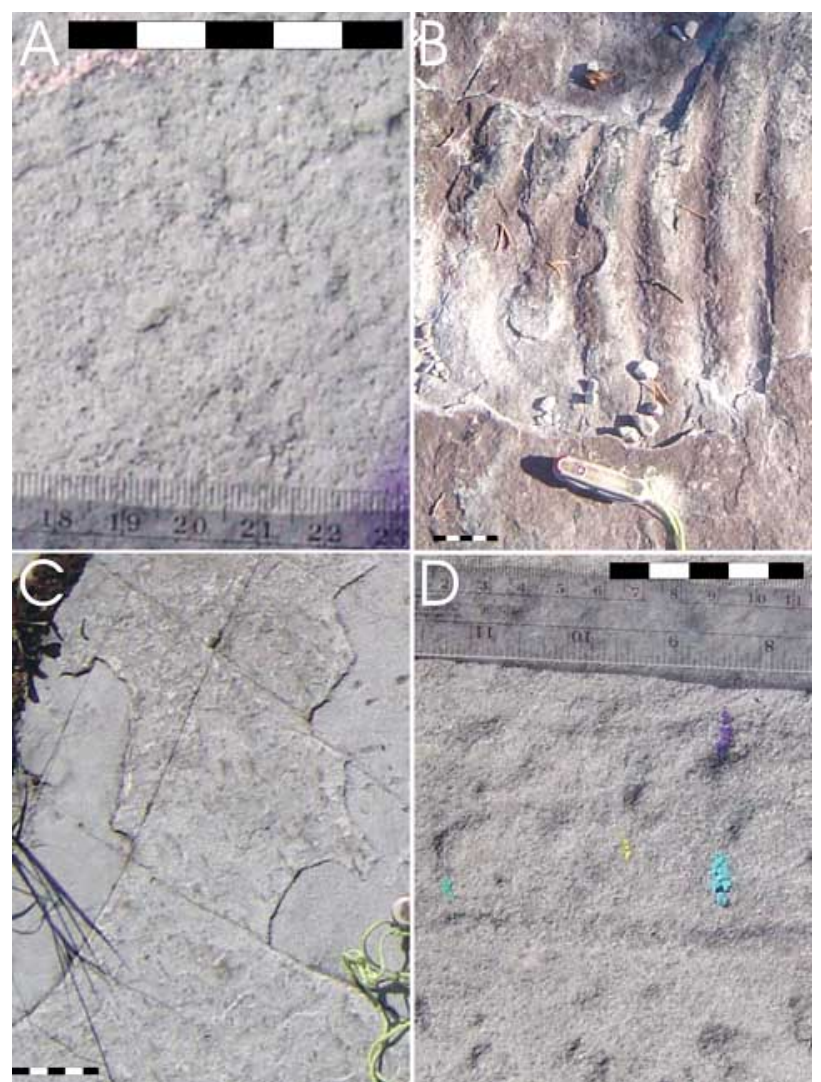

Fig. (5). Exposed bedding-plane textures at trackway locality. A) Microbial mat 'elephant skin' texture adjacent to trackway A. B) nearby ripple marks. C) laminar bedding overlaying preserved imprints at a nearby outcrop. D) A portion of trackway A, showing preservation of imprints.

Imprints within the medial impression do not seem to be swimming "launch" marks [65]; trackways typically disappear under an overlying bedding plane and lack telltale linear scratches.

This interpretation agrees with that of Logan $[23,26]$ and Owen [24, 25]. Although Owen never explicitly described the direction the organisms were progressing when they produced the trackways he studied, Logan later [66] revealed that the medial impression not only cut across ripple marks but showed a displacement of sand indicating travel in the direction of "a diverging arrangement of the successive answering pairs" (p. 105).

Owen, rather than finding a linear formation of tracks in each series as we have, arranged the track series of $P$. septemnotatus as three successive groups (A, B, and C) of track pairs on one side of the medial impression (Fig. 2). Each group was made up of either two (group B, consisting of tracks b and b') or three (groups A and C, comprising tracks a, a', a" and c, c', c"; however tracks c' and c" were considered a single divided track and track a did not form a line with a' and a", so these were essentially ignored. This allowed Owen [25] to describe the track arrangement as "disposed in pairs, placed with different degrees of obliquity, in each of the three groups, towards the median track," (p. 214) and it was these pairs that Logan seems to have been

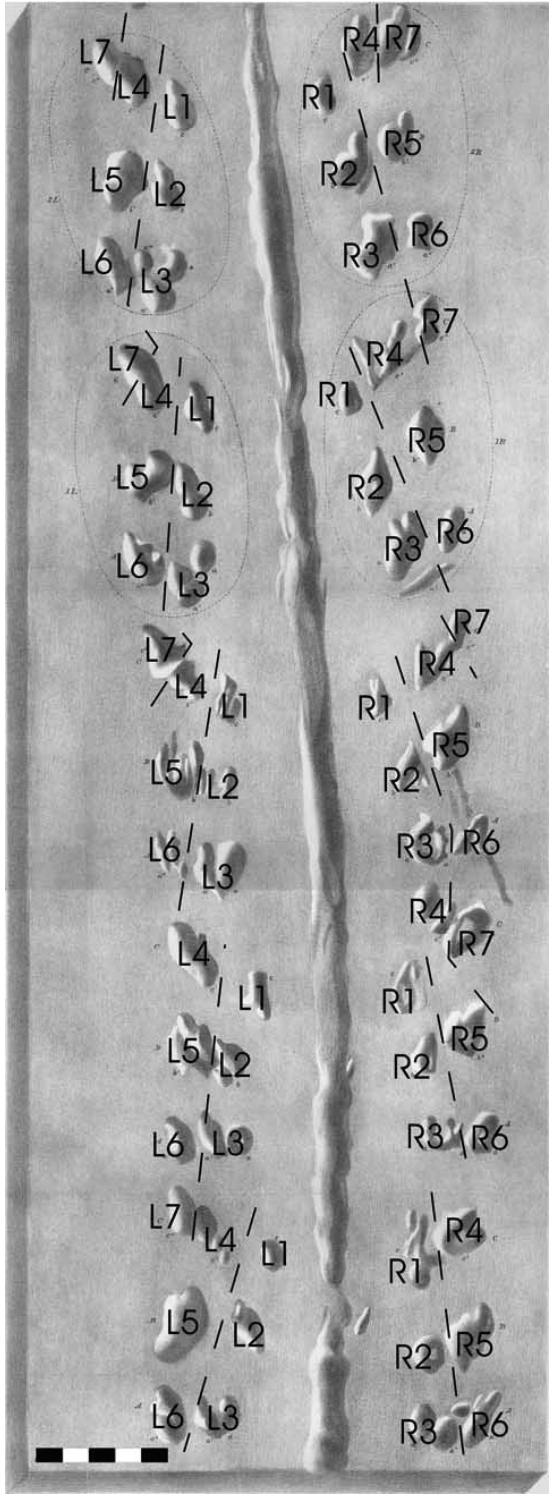

Fig. (6). Plate IX from Owen's [25] original description of Protichnites septemnotatus. Track series are labeled according to the interpretation applied to the trackways described herein. Direction of travel was toward top of figure. Scale bar is $5 \mathrm{~cm}$.

referring to rather than paired tracks across the midline, resulting in a direction of travel that was diverging forward under Owen's interpretation and converging forward under ours. In further support, the original Protichnites plates [25] are oriented so to be read with this interpreted direction of travel toward the top, with opposite track series labeled in what we can only assume to be the "left" and "right" of the producing organism.

\section{CONCLUSIONS}

The Protichnites (sensu Owen [25]) trackways described herein were produced by a Late Cambrian arthropod possessing seven pairs of walking limbs and a telson. More limbs could have been held out of contact with the substrate. The substrate exhibits structures (ripples and microbial mat textures) suggestive of a high inter-tidal/low subaerial or 
tidal pool environment. The producers of these trackways were not entirely terrestrial-no confirmed fully-terrestrial arthropods of this type have been found in sediments of similar age. No specific producer could be identified due to lack of both body fossils in the Potsdam Sandstone and of arthropods anywhere else in the fossil record with morphology that could have produced trackways of this type.

Protichnites ichnospecies can be identified as trackways possessing a single medial longitudinal impression (discontinuous or continuous) and a definite (integer) number of tracks per trackset, paired (i.e., opposing) across the midline. It is the hope of the authors that this description and the data collected pertaining to the individual imprints making up these trackways will be useful in comparing them to specimens of Protichnites found elsewhere. Because all ichnofossils are assigned according to form rather than nature of producer, it seems inherently appropriate to use quantitative morphometric data, such as have been provided herein, to describe arthropod trackways. However, such data collection in the past has seldom been completed, leaving behind an overly-broad definition of Protichnites and a lack of included ichnospecies. If all the named ichnospecies of Protichnites are to remain within the ichnogenus, ichnospecies will need to be distinguished by morphometric data rather than by qualitative means.

\section{ACKNOWLEDGEMENTS}

The junior author wishes to gratefully acknowledge many stimulating interactions over the years with the late W. T. Elberty, Jr. and E. L. Yochelson and ichnological discussions with T. W. Bjerstedt. The authors also wish to thank J. C. Dawson, without whom these occurrences would not have been located. C. W. Stevens assisted in field examination of the site. V. Millien graciously allowed the senior author (assisted by R. Cargill) to study specimens housed at Redpath Museum. R. M. H. Smith and S. Kaal were kind enough to provide photographs of material which could not be visited in person, as did R. B. MacNaughton. Comments of a half-dozen reviewers have broadened and improved this manuscript, and we appreciate those efforts. Additional review was provided by $\mathrm{T}$. Justham and A. Finstad. The senior author wishes to thank J. Hartman for continual support.

\section{REFERENCES}

[1] Drosser ML, Hughes NC, Jell PA. Palaeoecology of CambroOrdovician nearshore sandstones: trace fossil evidence from Mootwingee, New South Wales, Australia. Lethaia 1994; 27: 27383.

[2] Drosser ML, Fortey RA, Li X. The Ordovician radiation. Am Sci 1996; 84: 122-32.

[3] Valentine JW, Jablonski D, Erwin DH. Fossils, molecules and embryos: new perspectives on the Cambrian explosion. Development 1999; 126: 851-9.

[4] Bengtson S, Zhao Y. Fossilized metazoan embryos from the earliest Cambrian. Science 1997; 277: 1645-8.

[5] Zhang XG, Pratt BR. Middle Cambrian arthropod embryos with blastomeres. Science 1994; 266: 637-9.

[6] Chen JY, Oliver P, Li CW, et al. Precambrian animal diversity: putative phosphatized embryos from the Doushantuo Formation of China. Proc Natl Acad Sci USA 2000; 97(9): 4457-62.

[7] Hagadorn JW, Dott RH, Damrow D. Stranded on a Late Cambrian shoreline: medusae from central Wisconsin. Geology 2002; 30(2): 147-50.
[8] Hagadorn JW, Belt ES. Stranded in upstate New York: Cambrian scyphomedusae from the Potsdam Sandstone. Palaios 2008; 23: 424-41.

[9] Erickson JM. A preliminary evaluation of dubiofossils from the Potsdam Sandstone. In: Bursnall JT, Ed. Field Trip Guidebook to the 65th Annual Meeting, New York State Geological Association, St. Lawrence University, Canton, NY. St. Lawrence University 1993; p. 1-271.

[10] Hagadorn JW, Bottjer DJ. Wrinkle structures: microbially mediated sedimentary structures common in subtidal siliciclastic settings at the Proterozoic-Phanerozoic transition. Geology 1997; 25(11): 1047-50.

[11] Bottjer DJ, Hagadorn JW, Dornbos SQ. The Cambrian substrate revolution. GSA Today 2000; 10: 1-7.

[12] Schieber J, Bose PK, Eriksson PG, et al., Eds. Atlas of microbial mat features preserved within the siliciclastic rock record. Atlases in the Geosciences 2. Elsevier: New York 2007.

[13] Drosser ML, Bottjer DJ. A semi-quantitative field classification of ichnofabric. J Sediment Petrol 1986; 56: 558-9.

[14] Yochelson EL, Fedonkin MA. Paleobiology of Climactichnites, an enigmatic late cambrian fossil. Smith Contrib Paleobiol 1993; 74.

[15] Drosser ML, Jensen S, Gehling JG. Trace fossils and substrates of the terminal Proterozoic-Cambrian transition: Implications for the record of early bilaterians and sediment mixing. Proc Natl Acad Sci USA 2002; 99(20): 125-75.

[16] Tetlie OE, Moore RA. A new specimen of Paleomerus hamiltoni (Arthropoda; Arachnomorpha). Trans Roy Soc Edinburgh-Earth Sci 2004; 94: 195-8.

[17] Vaccari NE, Edgecombe GD, Escudero C. Cambrian origins and affinities of an enigmatic fossil group of arthropods. Nature 2004; 430: 554-7.

[18] Rudkin DM, Young GA, Nowlan GS. The oldest horseshore crab: a new xiphosurid from the Late Ordovician Konservat-Lagerstatten deposits, Manitoba, Canada. Palaeontology 2008; 51(1): 1-9.

[19] MacNaughton RB, Cole JM, Dalrymple RW, Braddy SJ, Briggs DEG, Lukie TD. First steps on land: arthropod trackways in Cambrian-Ordovician eolian sandstone, southeastern Ontario, Canada. Geology 2002; 30(5): 391-4.

[20] Erickson JM. Earliest evidence of invertebrate sexual behavior, or a tidal flat traffic jam in the Potsdam Fm. (Late Cambrian)? Geol Soc Am Abstr Prog 2004; 36(5): 66.

[21] Hoxie CT. Late Cambrian arthropod trackways in subaerially exposed environments: incentives to simplify a problematic ichnogenus. Amherst College: USA 2005.

[22] Fischer WA. The habitat of the early vertebrates: trace and body fossil evidence from the Harding Formation (Middle Ordovician), Colorado. Mount Geol 1978; 15(1): 1-26.

[23] Logan WE. On the occurrence of a track and foot-prints of an animal in the Potsdam Sandstone of lower Canada. Q J Geol Soc Lond 1851; 7: 247-50.

[24] Owen R. Descriptions of impressions on the Potsdam Sandstone, discovered by Mr. Logan in lower Canada. Q J Geol Soc Lond 1851; 7: 250-2.

[25] Owen R. Description of the impressions and footprints of the Protichnites from the Potsdam Sandstone of Canada. Q J Geol Soc Lond 1852; 8: 214-25.

[26] Logan WE. On the footprints occurring in the Potsdam sandstone of Canada. Q J Geol Soc Lond 1852; 8: 199-213.

[27] MacNaughton RB, Hagadorn JW. Report on plaster casts of arthropod-produced trace fossils (Protichnites) figured in W.E. Logan's Geology of Canada (1863), and recently copied from material in the Amherst College Museum of Natural History, Amherst, MA. Geological Survey of Canada 2006.

[28] Getty PR, Hagadorn JW. Paleobiology of the Climactichnites tracemaker. Palaeontology 2009; 54(4): 753-78.

[29] Fillion D, Pickerill RK. Ichnology of the Upper Cambrian? to Lower Ordovician Bell Island and Wabana groups of eastern Newfoundland, Canada. Palaeontograph Can 1990; 7: 1-119.

[30] Bjerstedt TW, Erickson JM. Trace fossils and bioturbation in peritidal facies of the Potsdam-Theresa Formations (CambrianOrdovician), northwest Adirondacks. Palaios 1989; 4(3): 203-24.

[31] Braddy SJ. Ichnological evidence for the arthropod invasion of land. Fossils Strata 2004; 51: 136-40.

[32] Landing E, Franzi DA, Hagadorn JW, Westrop SR, Kröger B, Dawson JC. Cambrian of East Laurentia: Field Workshop in Eastern New York and Vermont. In: Landing E, Ed. Ediacaran- 
Ordovician of East Laurentia-S. W. Ford Memorial. New York State Museum Bulletin 510. New York State Museum; 2007; p. 2571.

[33] Sanford BV. Stratigraphic and structural framework of the Potsdam Group in eastern Ontario, western Quebec and northern New York. University of Ottawa, Ottawa: Canada 2007.

[34] Burton-Kelly ME, Erickson JM. An analysis of multiple trackways of Protichnites Owen, 1852, from the Potsdam Sandstone (Late Cambrian), St. Lawrence Valley, NY. GSA Abs Prog 2005; 37(1): 13.

[35] Häntzschel W. Trace fossils and problematica: In: Moore RC, Ed. Treatise on Invertebrate Paleontology, Part W (Miscellanea). Boulder and Lawrence: Geological Society of America and University of Kansas Press 1962.

[36] Walcott CD. Cambrian geology and paleontology II No. 9-New York Potsdam-Hoyt fauna. Sm Misc Col 1912; 57(9): 252-305.

[37] Bradley WH. Lower Silurian reptile in Canada. Am J Sci 1851; 12(2): 120-1.

[38] International Commission on Zoological Nomenclature. $4^{\text {th }}$ ed; International Code of Zoological Nomenclature, 1999.

[39] Hitchcock E. Ichnology of New England: A report on the sandstone of the Connecticut Valley, especially its fossil footmarks. Boston: William White 1858.

[40] Keighley DG, Pickerill RK. Systematic ichnology of the Mabou and Cumberland groups (Carboniferous) of western Cape Breton Island, eastern Canada, 2: surface markings. Atlantic Geol 1998; 34: 83-112.

[41] Seilacher A. Spuren und Lebenspuren der Trilobiten. In: Schindewolf $\mathrm{OH}$, Seilacher A, Eds. Beitrage zur Kenntnis des Kambriums in der Salt Range (Pakistan). Akademiee der Wissenschaften und der Litaratur zu Mainz, mathematischnaturwissenschaftliche Klasse, Abhandlungen, 10; 1955. pp. 37399.

[42] Häntzschel W. Trace Fossils and Problematica: In Moore, R.C., Ed. Treatise on Invertebrate Paleontology $\left(2^{\text {nd }}\right.$ ed.), Part W (Miscellanea). Boulder and Lawrence: Geological Society of America and University of Kansas Press 1975.

[43] Trewin NH, McNamara KJ. Arthropods invade the land: trace fossils and palaeoenvironments of the Tumblagooda Sandstone (Late Silurian) of Kalbarri, Western Australia. Trans Roy Soc Edinburg-Earth Sci 1995; 85: 177- 210.

[44] Burton-Kelly ME. An analysis of multiple trackways of Protichnites Owen, 1852, from the Potsdam Sandstone (Late Cambrian), St. Lawrence Valley, NY, unpublished Bachelor's thesis. St. Lawrence University 2005.

[45] Gerdes G, Klenke T, Noffke N. Microbial signatures in peritidal siliciclastic sediments: a catalogue. Sedimentology 2000; 47: 279308.

[46] Noffke N. Erosional remnants and pockets evolving from bioticphysical interactions in a Recent lower supratidal environment. Sediment Geol 1999; 123: 175-81.

[47] Minter NJ, Braddy SJ, Davis RB. Between a rock and a hard place: arthropod trackways and ichnotaxonomy. Lethaia 2007; 40: 36575.

[48] Trewin NH. A draft system for the identification and description of arthropod trackways. Palaeontology 1994; 37(4): 811-23.
[49] Anderson AM. The "trilobite" trackways in the Table Mountain Group (Ordovician) of South Africa. Palaeontol Afr 1975; 18: 3545.

[50] Logan WE. On the tracks of an animal lately found in the Potsdam Formation. Can Nat Geol 1860; 5: 279-85.

[51] Donaldson A, Chiarenzelli J. Stromatolites and associated biogenic structures in Cambrian and Ordovician strata in and near Ottawa, Ontario. In: Badger R, Ed. New York State Geological Association 76th annual meeting field trip guidebook. Potsdam, NY: SUNY Potsdam 2004. pp. 1-20.

[52] Sharpe SCF. Eurypterid trail from the Ordovician. Am J Sci 1932; 24: 355-61

[53] Taljaard MS. On the palaeogeography of the Table Mountain Sandstone Series. S Afr Geogr J 1962; 44: 25-7.

[54] Hagadorn JW, Seilacher A. Hermit arthropods 500 million years ago? Geology 2009; 37(4): 295-8.

[55] Braddy SJ, Almond JE. Eurypterid trackways from the Table Mountain Group (Ordovician) of South Africa. J Afr Earth Sci 1999; 29(1): 165-77.

[56] Bertling M, Braddy SJ, Bromley RG, et al. Names for trace fossils: a uniform approach. Lethaia 2006; 39: 265-86.

[57] Briggs DEG, Rolfe WDI, Brannan J. A giant myriapod trail from the Namurian of Arran, Scotland. Palaeontology 1979; 22(2): 27391.

[58] Curran HA. Ichnology of Pleistocene carbonates of San Salvador, Bahamas. J Paleontol 1984; 58: 312-321.

[59] Braddy SJ, Dunlop JA. The functional morphology of mating in the Silurian eurypterid, Baltoeurypterus tetragonophthalmus (Fischer, 1839). Zool J Linn Soc-Lond 1997; 121: 435-61.

[60] Collette JH. A window into the Cambrian: exceptionally preserved arthropods from Quebec and Wisconsin. Geol Soc Am Abstr Prog 2008; 40(6): 203.

[61] Young GA, Rudkin DM, Dobrzanski EP, Robson SP, Nowlan GS. Exceptionally preserved Late Ordovician biotas from Manitoba, Canada. Geology 2007; 35: 883-6.

[62] Penn D, Brockmann HJ. Age-based stranding and righting in male horseshoe crabs, Limulus polyphemus. Anim Behav 1995; 49: 1531-9.

[63] Fisher DC. Righting behavior and optimization of telson length in horseshoe crabs (Chelicerata: Xiphosura). J Paleontol 1977; 51 (Suppl III): 11.

[64] Hanken NM, Störmer L. The trail of a large Silurian eurypterid. Fossils Strata 1975; 4: 255-70.

[65] Braddy SJ, Milner ARC. A large arthropod trackway from the Gaspé Sandstone Group (Middle Devonian) of eastern Canada. Can J Earth Sci 1998; 35: 1116-22.

[66] Logan WE. The Geology of Canada. Dawson Brothers: UK 1863.

[67] Braddy SJ. The ichnotaxonomy of the invertebrate trackways of the Coconino Sandstone (Lower Permian), Northern Arizona. In: Lucas SG, Heckert AB, Eds. Early footprints and facies. New Mexico Museum of Natural History and Science Bulletin No. 6. New Mexico Museum of Natural History and Science 1995; pp. 219-24.

[68] Braddy SJ, Briggs DEG. New Lower Permian nonmarine arthropod trace fossils from New Mexico and South Africa. J Paleontol 2002, 76(3): 546-57. 